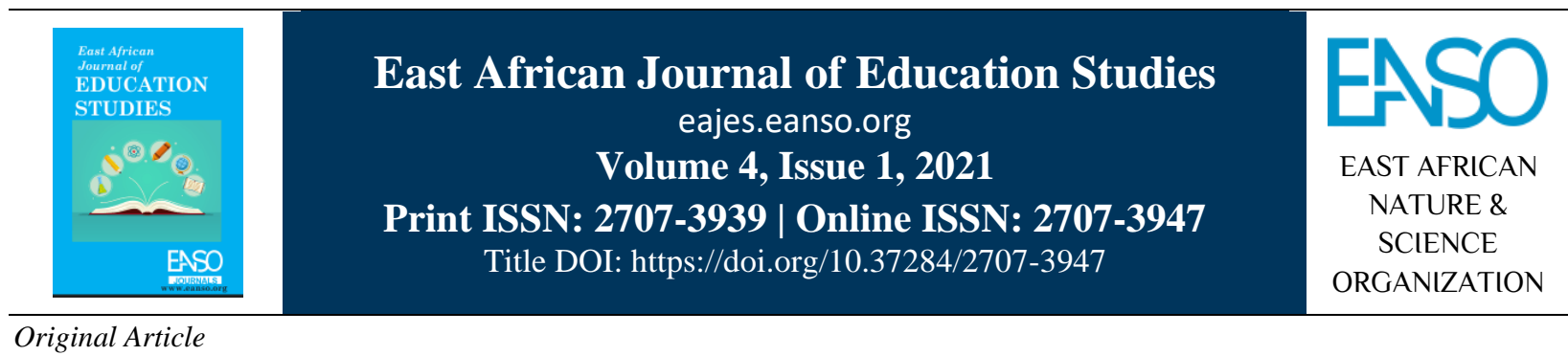

\title{
Influence of Teaching Skills and Training Methodology on Performance of Learners with Visual Impairment in Public Primary Schools in Narok West Sub-County, Kenya.
}

\author{
Tonui Elijah ${ }^{1^{*}}$ Dr. Ruth Nyambura, PhD ${ }^{1} \&$ Dr. Peterson Oigara, PhD ${ }^{1}$ \\ 1* Mount Kenya University, P. O. Box 342-01000, Thika, Kenya. \\ *Correspondence Email: tonuielijah883@gmail.com.
}

Article DOI: https://doi.org/10.37284/eajes.4.1.421

\begin{abstract}
Date Published: ABSTRACT
30 September 2021 The study sought to assess the influence of teaching skills and training methodology on the performance of learners with visual impairment in public

Keywords: primary schools in Narok West Sub-County, Kenya. The study analysed past

Teaching skills, theories related to the topic under the theoretical review that is Education

Production Function (EPF) theory. The researcher used a descriptive research Methodology, design to capture the information on the influence of teaching skills and Performance training methodology. The findings indicated that teaching skills and training methodology influence the performance of learners with visual impairment in public primary schools in the Narok West Sub-County.
\end{abstract}

\section{APA CITATION}

Elijah, T., Nyambura, R. \& Oigara, P. (2021). Influence of Teaching Skills and Training Methodology on Performance of Learners with Visual Impairment in Public Primary Schools in Narok West Sub-County, Kenya. East African Journal of Education Studies, 3(1), 1-6. https://doi.org/10.37284/eajes.4.1.421.

\section{CHICAGO CITATION}

Elijah, Tonui, Ruth Nyambura and Peterson Oigara. 2021. "Influence of Teaching Skills and Training Methodology on Performance of Learners with Visual Impairment in Public Primary Schools in Narok West Sub-County, Kenya". East African Journal of Education Studies 3 (1), 1-6. https://doi.org/10.37284/eajes.4.1. 421.

\section{HARVARD CITATION}

Elijah, T., Nyambura, R. and Oigara, P. (2021) "Influence of Teaching Skills and Training Methodology on Performance of Learners with Visual Impairment in Public Primary Schools in Narok West Sub-County, Kenya", East African Journal of Education Studies, 3(1), pp. 1-6. doi: 10.37284/eajes.4.1. 421.

\section{IEEE CITATION}

T. Elijah, R. Nyambura, and P. Oigara, "Influence of Teaching Skills and Training Methodology on Performance of Learners with Visual Impairment in Public Primary Schools in Narok West Sub-County, Kenya”, EAJES, vol. 4, no. 1, pp. 1-6, Sep. 2021.

1 | This work is licensed under a Creative Commons Attribution 4.0 International License. 


\section{MLA CITATION}

Elijah, Tonui, Ruth Nyambura and Peterson Oigara. "Influence of Teaching Skills and Training Methodology on Performance of Learners with Visual Impairment in Public Primary Schools in Narok West Sub-County, Kenya". East African Journal of Education Studies, Vol. 4, no. 1, Sep. 2021, pp. 1-6, doi:10.37284/eajes.3.1.421.

\section{INTRODUCTION}

Globally, the importance of education to pupils with special needs has been debated for long under various monitory organisations. The development of special education for pupils with disabilities in inclusive schools has been on the rise with international bodies putting declarations on education for all as a fundamental right for all in the society (UNESCO, 2015). Through the Salamanca policy statement and education framework developed in 1994, Kenya adopted its elements and put lots of emphasis on inclusivity in schools to admit all pupils in regular learning irrespective of the social and physical inability, differed knowledge capacity or responsive inability or any other conditions that may thwart the commitment towards adoption of inclusive education. Similarly, the current education system in Kenya has enacted policies that focus on the implementation of Education for All (EFA), which was established by an act of parliament in 2003 (Orodho, 2014). This policy has also been applied in the majority of primary public schools in the Narok West constituency where pupils of diverse needs are put together in the same learning environment. Within this policy framework of enhancing knowledge acquisition for all pupils, there is a need for the government to revamp its commitment towards global policy statements, practices and agreements as indicated in numerous world symposiums on excellent education and embrace inclusive education not only in public schools but also in private schools countrywide (Miles \& Singal, 2010).

Customarily, education regarding pupils with disabilities has shown indolent efforts in the implementation of workable policies in public schools. The focus on the right of pupils with disabilities in social interactions, especially for people with visual impairments has not shown significant commitment towards their special needs education in an inclusive society (Leader \& Leahy, 2015). The development of inclusive and excellent education was recognised as a major step toward human development in society in the early 1900s.
During this time, special schools to cater for children who are visually impaired were established in the United States of America since pupils who were visually impaired had the competency of schooling and becoming autonomous in society. In 1902, a regular day class for the blind pupils was founded in Chicago which was meant to provide schooling services to the pupils in the society. Generally, by 1930, almost 50 schools were serving pupils with visual impairment in local schools. After four decades, nearly in the 1970s, the period was marked with sensitisation and recognition of special needs including pupils who are visually impaired in the society. During this era, educators and parents created awareness of the need for including arrays of service in regular options for pupils with visual impairments in public entities and institutions at large (Douglas \& Mwaura, 2011).

Mancera and Schmolkes (2010) argue that teacher training in special education has led to improved teaching skills, approaches of communication and a modified curriculum that has increased the number of learners with visual impairments in schools. Therefore, the need for the learners to be catered for in order to perform well in examinations and other forms of assessment has risen. The Government of Kenya has employed supervisory efforts in following up on policies that govern the education of learners with special needs in education while giving educators prior necessary skills required to support pupils with impairments who attend a regular or special school. This initiative from the government has made a drastic increase in the enrolment of pupils with visual impairment in public primary schools in the Narok West SubCounty. To assure inclusion and quality services, pupils with visual impairment, therefore, should be given social support for them to feel inclusivity both emotionally and mentally which would facilitate them to perform well in examinations as sighted peers (MOEST, 2013). This study, therefore, focused on finding out the influence of teaching skills and training methodology on the performance of learners with visual impairment in public primary schools in the Narok West Sub-County.

2 | This work is licensed under a Creative Commons Attribution 4.0 International License. 


\section{THEORETICAL FRAMEWORK}

The study was based on the Education Production Function (EPF) theory

\section{Education Production Function (EPF) Theory}

The theory was used to provide a basis for understanding better the cognitive approaches to education through cost-effective planning approaches (Brewer \& McEwan, 2010). The EPF theory advocates that education outcomes are a function of inputs from the assorted components associated with the teaching process that is provided primarily by teachers as principal components and output measured by student's performances. Variation of one component as inputs is most likely to have an impact on any other desired outputs. The theory was found suitable because teachers' efficiency level in work related to performance termed as 'students' academic performance' is a utility of countless teacher contributions towards teaching and learning process. Therefore, teachers' preparedness in this situation may be evaluated on the level of teacher lesson preparation, classroom management strategies application and skills that ensure pupils are competent and perform well. Therefore, adequate teacher preparedness brings teacher training efficiency which can be derived from the degree of teachers' knowledge on how to conduct the teaching-learning process.

The relationship between teacher inputs and teacher preparedness is when teachers are deemed wellorganised while teaching any unit in a classroom environment. For pupils with VI, their academic achievement can be realised when teachers efficiently collaborate and work together with the entire administrative operations to achieve desired goals for integration in the teaching and learning process. Education is perceived as a social system in which its components are embedded in the manner that they interrelate in the educational environs. EPF theory places teachers at the core centre of interactive structures that represent proximal and close relationships on teaching and learning processes of pupil's life for the transition experience through knowledge. Through proximal processes, pupils are able to have face-to-face relationships with teachers and which significantly influence learner's life. The theory provides a social framework that brings to understanding the personal influences which affect the performance of the learners with VI in public primary schools. Teachers' preparedness in the academic field has been emphasised as the key aspect in providing pupils with the required pedagogical knowledge for personality development and academic achievements. Therefore, EPF acknowledges the shared responsibility of all components through creating dynamic nature of the relationships involved in the learning process. The study, therefore, was guided by this theory to model the relationships in assessing how teachers' teaching skills and training methodology influence the performance of learners with visual impairment in public schools in the Narok West Sub-County.

\section{METHODOLOGY AND DESIGN}

This study adopted a descriptive survey design. According to Orodho (2009), the descriptive survey is the engagement of a sample population in a bid to get their views, beliefs, attitudes, opinion among other attributes that allow the person to pass information through interviews and questionnaires. Description of attitudes, beliefs, opinions and other personal attributes done in research using a survey (Wambalaba, 2009). The researcher used both questionnaires and interview schedules during data collection making the design very appropriate. The descriptive nature of the research design was used in order to collect information on the influence of teachers' teaching skills and training methodology on the performance of learners with visual impairment in public schools in the Narok West Sub-County. This design provides a quantitative and numeric description of trends, attitudes and/or opinions of a population being studied by having a sample of that population. The researcher generalised and made claims about the general population from the sample population.

\section{RESULTS AND DISCUSSION}

The study sought to establish the influence of teaching skills and training methodology on the performance of learners with visual impairment in public schools in the Narok West Sub-County. The findings are indicated in Table 1.

3 | This work is licensed under a Creative Commons Attribution 4.0 International License. 
Table 1: Teacher's Perceptions on Influence of Teaching Skills and Training Methodology on Performance of Pupils with Visual Impairments

\begin{tabular}{|c|c|c|c|c|c|c|c|}
\hline Description & SD & D & $\mathbf{U}$ & $\mathbf{A}$ & SA & Mean & $\begin{array}{l}\text { Std } \\
\text { Dev }\end{array}$ \\
\hline $\begin{array}{l}\text { Teachers have appropriate skills to } \\
\text { train pupils with visual impairment } \\
\text { in the school }\end{array}$ & $\begin{array}{l}8 \\
(6.6 \%)\end{array}$ & $\begin{array}{l}42 \\
(34.7 \%)\end{array}$ & - & $\begin{array}{l}56 \\
(46.3 \%)\end{array}$ & $\begin{array}{l}14 \\
(11.6 \%)\end{array}$ & 3.22 & 1.231 \\
\hline $\begin{array}{l}\text { Teachers regularly attend training } \\
\text { on special needs to improve skills } \\
\text { on how to teach pupils with visual } \\
\text { impairment }\end{array}$ & $\begin{array}{l}10 \\
(8.3 \%)\end{array}$ & $\begin{array}{l}42 \\
(34.7 \%)\end{array}$ & $\begin{array}{l}15 \\
(12.4 \%)\end{array}$ & $\begin{array}{l}51 \\
(42.1 \%)\end{array}$ & $\begin{array}{l}2 \\
(1.7 \%)\end{array}$ & 2.94 & 1.087 \\
\hline $\begin{array}{l}\text { A pupil with visual impairment is } \\
\text { given special attention and extra } \\
\text { time to complete the task by } \\
\text { teachers in classes }\end{array}$ & - & $\begin{array}{l}8 \\
(6.6 \%)\end{array}$ & $\begin{array}{l}11 \\
(9.1 \%)\end{array}$ & $\begin{array}{l}58 \\
(7.9 \%)\end{array}$ & $\begin{array}{l}41 \\
(33.9 \%)\end{array}$ & 4.12 & 0.839 \\
\hline $\begin{array}{l}\text { Teachers always spend additional } \\
\text { time in class to educate learners } \\
\text { with visual impairment }\end{array}$ & $\begin{array}{l}8 \\
(6.6 \%)\end{array}$ & $\begin{array}{l}2 \\
(1.7 \%)\end{array}$ & $\begin{array}{l}2 \\
(1.7 \%)\end{array}$ & $\begin{array}{l}76 \\
(62.8 \%)\end{array}$ & $\begin{array}{l}32 \\
(26.4 \%)\end{array}$ & 4.02 & 0.979 \\
\hline $\begin{array}{l}\text { Teachers boost learners' } \\
\text { understanding through integrating } \\
\text { text, symbols and illustration in } \\
\text { class }\end{array}$ & $\begin{array}{l}2 \\
(1.7 \%)\end{array}$ & $\begin{array}{l}18 \\
(14.9 \%)\end{array}$ & $\begin{array}{l}18 \\
(14.9 \%)\end{array}$ & $\begin{array}{l}59 \\
(48.8 \%)\end{array}$ & $\begin{array}{l}23 \\
(19 \%)\end{array}$ & 3.69 & 1.002 \\
\hline
\end{tabular}

Teachers were asked to indicate their perceptions on the influence of teaching skills and training methodology on the performance of people with visual impairments. From Table 1, 8 (6.6\%) respondents strongly disagreed when asked whether teachers have appropriate skills to train pupils with visual impairment in the school. $42(34.7 \%)$ respondents disagreed, majority of $56(46.3 \%)$ respondents agreed, $14(11.6 \%)$ respondents strongly agreed and $1(0.8 \%)$ respondent did not answer. The mean for this was 3.22 with a standard deviation of 1.231. The study findings corroborated the findings of Lynch et al. (2011), who found out that the teachers have got what it takes to handle pupils with visual impairment.

When asked whether teachers regularly attend training on special needs to improve skills on how to teach pupils with visual impairment, $10(8.3 \%)$ respondents strongly disagreed, 42 (34.7\%) respondents disagreed, 15 (12.4\%) respondents did not answer, majority of $51(42.1 \%)$ respondents agreed, 2 (1.7\%) respondents strongly agreed and 1 $(0.8 \%)$ respondent did not answer. The mean for this was 2.94 with a standard deviation of 1.087 . The findings of the study were in agreement with the findings of De Boer, Pijl and Minnaert (2011), who in their findings they found out that training is not always attended by teachers so as to take up the task of teaching learners with visual impairments.

Furthermore, teachers were asked whether pupils with visual impairment are given special attention and extra time to complete the task by teachers in classes. $8(6.6 \%)$ respondents disagreed, $11(9.1 \%)$ respondents were undecided, majority of $58(7.9 \%)$ respondents agreed, 41 (33.9\%) respondents strongly agreed and $3(2.5 \%)$ respondents did not answer. The mean for this was 4.12 with a standard deviation of 0.839 . Concerning whether teachers always spend additional time in class to educate learners with visual impairment, 8 (6.6\%) respondents strongly disagreed, 2 (1.7\%) respondents disagreed, $2(1.7 \%)$ respondents were undecided, majority of $76(62.8 \%)$ respondents agreed, $32(26.4 \%)$ respondents strongly agreed and $1(0.8 \%)$ respondent did not answer. The mean for this was 4.02 with a standard deviation of 0.979 . The findings of the study are in agreement with the findings of Habulezi and Phasha (2012), who in their study they indicated that these learners need specialised attention.

4 | This work is licensed under a Creative Commons Attribution 4.0 International License. 
Lastly, based on the second objective, teachers were asked whether they boost learners' understanding through integrating text, symbols and illustrations in class. $2(1.7 \%)$ respondents strongly disagreed, 18 (14.9\%) respondents disagreed, 18 (14.9\%) respondents were undecided, majority of 59 $(48.8 \%)$ respondents agreed, $23(19 \%)$ respondents strongly agreed and $1(0.8 \%)$ respondent did not answer (see Table 1). The mean for this was 3.69 with a standard deviation of 1.002. The study findings corroborated the findings of Schmeck et al., 2014), who in their study found out that integrating text, symbols and illustrations is the way to boost learners understanding.

Further findings from the interviews indicated braille textbooks and handouts could enhance efficiency towards teaching in integrated public schools for regular pupils and those with visual impairment and that the support accorded by the school administration and community providers is providing a budget and actualising the budget when called upon to. The headteachers sampled for the study expressed enthusiasm from the community to see that the learners with visual impairments get an education just like every other child.

\section{CONCLUSION}

From the findings of the study, the study came to a conclusion that teacher's teaching skills and training methodology influence the performance of learners with visual impairment in public schools in Narok West Sub-County This is because teachers have appropriate skills to train pupils with visual impairment and they regularly attend training on special needs to improve skills on how to teach those pupils. Pupils with visual impairment are given special attention and extra time to complete the tasks and teachers always spend additional time in class to educate them. Also, teachers boost learners' understanding through integrating text, symbols and illustrations in class.

\section{Recommendation of the Study}

The following recommendations were made: -

- Teachers should be enriched with appropriate skills to train pupils with visual impairment. Based on the study, a good number disagreed that they have appropriate skills even though a majority of them agreed.

- The ministry of education should look into ways of improving the performance of learners with visual impairment in public schools. Based on the study, there has been a low performance of learners with visual impairments.

\section{REFERENCES}

Brewer, D. J., \& McEwan, P. J. (Eds.). (2010). Economics of education. Elsevier.

De Boer, A., Pijl, S. J., \& Minnaert, A. (2011). Regular primary schoolteachers' attitudes towards inclusive education: A review of the literature. International journal of inclusive education, 15(3), 331-353.

Douglas, G., \& Mwaura, M., (2011). Inclusive educational practices in Kenya: Evidencing practice of itinerant teachers who work with children with visual impairment in local mainstream schools. International Journal of Educational Development, 31(5), 478-488

Habulezi, J., \& Phasha, T. N. (2012). Provision of learning support to learners with visual impairment in Botswana: A case study. Procedia-Social and Behavioural Sciences, 69, 1555-1561.

Leader, G., \& Leahy, M. (2015). Defining social inclusion of people with intellectual and developmental disabilities: An ecological model of social networks and community participation. Research in developmental disabilities, 38, 18-29.

Lynch, P., McCall, S., Douglas, G., McLinden, M., Mogesa, B., Mwaura, M., ... \& Njoroge, M. (2011). Inclusive educational practices in Kenya: Evidencing practice of itinerant teachers who work with children with visual impairment in local mainstream schools. International Journal of Educational Development,31(5), 478-488.

Mancera, C., \& Schmolkes, S. (2010). Specific Policy Recommendations on the Development of

5 | This work is licensed under a Creative Commons Attribution 4.0 International License. 
a Comprehensive In-Service Teacher Evaluation Framework. OECD-Mexico

Miles, S., \& Singal, N. (2010). The Education for All and inclusive education debate: conflict, contradiction or opportunity? International journal of inclusive education, 14(1), 1-15.

MoEST. (2013). Sessional paper No. 1: A Policy framework for Education, Training and Research in Kenya in the $21^{\text {st }}$ Century. Nairobi: Government printers

Orodho, J. A. (2009). Elements of education and social science research methods. Nairobi/Maseno. Kanezja Publisher.

Orodho, J. A. (2014). Policies on free primary and secondary education in East Africa: Are Kenya and Tanzania on course to attain Education for All (EFA) Goals by 2015. International Organization of Scientific Research (IOSR) Journal of Humanities and Social Sciences (IOSR-JHSS), 19(1), 11-20.

Schmeck, A., Mayer, R. E., Opfermann, M., Pfeiffer, V., \& Leutner, D. (2014). Drawing pictures during learning from scientific text: Testing the generative drawing effect and the prognostic drawing effect. Contemporary Educational Psychology, 39(4), 275-286.

UNESCO. (2015). Education for All 2000-2015: Achievements and challenges. EFA Global Monitoring Report, 500

Wambalaba, F. W. (2009). Redefining the research scholarship and USIU.

6 | This work is licensed under a Creative Commons Attribution 4.0 International License. 